\title{
A CONTRACT CONTRADICTION
}

\author{
David McLauchlan*
}

This article attacks the well established principle of the law of contract that evidence of the parties' negotiations and subjective intentions is not receivable in an interpretation dispute. It argues that the principle is inconsistent with equally well established principles of contract formation. Numerous other reasons for rejecting the principle, including the absence of convincing practical or policy grounds, are also identified and discussed. The author concludes that the courts should never enforce an agreement in accordance with a meaning which reliable evidence may show is contrary to the actual intentions of the parties.

$I$

INTRODUCTION

The purpose of this article is to highlight what, in my view, is a contradiction in certain basic aspects of modern contract law doctrine. The contradiction is between the principles of contract formation and the principles of contract interpretation relating to the relevance of the actual or subjective intentions of the parties. According to these principles we are required to accept that while (a) evidence of the actual intentions of the parties is relevant and therefore admissible when the existence of a contract is in issue, nevertheless (b) when it comes to the interpretation of an admitted contract, evidence of their actual intentions concerning the meaning of the contract is irrelevant and therefore inadmissible. How can it be that the parties' actual intentions are irrelevant when the issue concerns the meaning of a term but relevant when the issue is whether an apparently complete contract is in fact a contract at all? Why is it that one cannot contradict the apparent meaning of a term of a contract but one can contradict an apparently complete contract? ${ }^{1}$

* Professor of Law, Victoria University of Wellington.

1 This article builds on, and repeats some of the views in, the following of my earlier works: "Actual Consensus Ad Idem in Contract - Unnecessary but Surely Sufficient?" [1995] NZLJ 45

["Actual Consensus"]; "The Plain Meaning Rule of Contract Interpretation" (1996) 2 NZ Business LQ 80 ["Plain Meaning Rule"]; "Subsequent Conduct as an Aid to Interpretation" 


\section{PRINCIPLES OF CONTRACT FORMATION}

It is true that there is an established general principle of the law of contract that an objective approach is adopted in determining questions of agreement and intention to be bound. Although the courts will often say that consensus ad idem or a "meeting of the minds" is required for the formation of a binding contract, it is clear that an apparent consensus will suffice. ${ }^{2}$ Thus, as Blackburn J stated in the well-known case of Smith $v$ Hughes: ${ }^{3}$

If, whatever a man's real intention may be, he so conducts himself that a reasonable man would believe that he was assenting to the terms proposed by the other party, and that other party upon that belief enters into the contract with him, the man thus conducting himself would be equally bound as if he had intended to agree to the other party's terms.

It follows that a person will be held to have made a contractual offer if it was reasonable for the alleged offeree to believe that he could conclude a contract simply by indicating assent to the former's terms. It is irrelevant that the offeror had not the slightest intention to be bound (because, for example, the promise was made in jest) if the offeree was reasonably entitled to think that the offeror did have that intention. Similarly, a response to an offer will amount to a binding acceptance, notwithstanding that the offeree did not intend it to be an acceptance, if the offeror reasonably so regarded it. Further, at common law a mistake by a promisor as to the terms of the contract (for example, she thinks she is buying properties $X$ and $Y$, not just property $\mathrm{X}$ ) does not prevent the formation of a binding contract where the promisee reasonably believes that the terms have been assented to.

It by no means follows, however, that the approach of the courts is wholly objective. The law is not solely concerned "with what a featureless reasonable addressee would have thought". ${ }^{4}$ Instead "it takes into account what a reasonable person standing in the addressee's

(1996) 2 NZ Business LQ 237 ["Subsequent Conduct"]; and "Common Assumptions and Contract Interpretation" (1997) 113 LQR 237 ["Common Assumptions"]. See also "A Contract With Its Own Meaning?" [1996] NZLJ 439 and "Subsequent Conduct and Contract Interpretation - An Update" (1997) 3 NZ Business LQ 147.

2 See, for example, Boulder Consolidated Ltd $v$ Tangaere [1980]1 NZLR 560, 567 (CA).

3 (1871) LR 6 QB 597,607.

4 Melvin A Eisenberg "The Responsive Model of Contract Law" (1984) 36 Stan L Rev 1107, 1121 ["Responsive Model"]. 
shoes - having the addressee's knowledge - would have thought". ${ }^{5}$ Thus, for example, whether an alleged offeree can reasonably infer the existence of an offer not intended by the offeror may depend on her knowledge of the offeror's characteristics (perhaps he is known to be an inveterate practical joker) or circumstances (perhaps he has no money or no ability to carry out the offer). Nor is the approach of the courts wholly objective in the sense they are unconcerned with the actual intentions or states of mind of the parties. As Blackburn J's statement in Smith $v$ Hughes itself makes clear, the objective principle involves a subjective element. ${ }^{6}$ It requires not only that a reasonable person would believe that the promisor was assenting to the terms proposed by the other party but also that "that other party upon that belief enters into the contract with him". Where, for example, the other party knows that the promise is made in jest or that the promisor is mistaken about the terms of the contract this requirement is not satisfied and the promise cannot be enforced in its "objective" sense. A party who alleges the formation of a binding contract because a reasonable person in her position would have been entitled to infer a contractual offer can only succeed if, in addition, she subjectively understood that there was an offer, ${ }^{7}$ although in practice this will be assumed in the absence of a challenge from the alleged offeror. ${ }^{8}$ The promisee's state of mind may even mean that she is bound to a contract which was not intended by her. Thus, knowledge that the promisor is mistaken as to the terms of an apparent contract may, in certain circumstances, result in the promisee being bound according to the promisor's understanding of the terms. ${ }^{9}$

$5 \quad$ "Responsive Model" above n 4, 1121.

6 See generally G H Treitel The Law of Contract (9 ed, Stevens, London, 1995) 1 and 8-9.

$7 \quad$ Paal Wilson \& Co A/S v Partenreederei Hannah Blumenthal [1983] 1 AC 854, 915-917 and 924 (HL). See also Embry v Hargadine, McKittrick Dry Goods Co (1907) 105 SW 777, 779 (Mo CA) discussed in "Responsive Model" above n 4, 1125-1126; Airways Corporation of New Zealand Ltd $v$ Geyersland Airways Ltd [1996] 1 NZLR 116, 124-125 (HC); Rattrays Wholesale Ltd v Meredith-Young \& A'Court Ltd [1997] 2 NZLR 363, 374 (HC); and Magnum Photo Supplies Ltd v Viko New Zealand Ltd [1999] 1 NZLR 395, 401 (CA).

8 Indeed, there is much to be said for the view that "the courts are entitled to assume, in the absence of proof to the contrary, that a party's subjective understanding of a transaction corresponded with the way in which a reasonable person in his position would have understood it": J P Vorster "A Comment on the Meaning of Objectivity in Contract" (1987) 103 LQR 274, 287.

9 See D W McLauchlan "Rectification for Unilateral Mistake" (1999) 18 NZULR (forthcoming). 
The objective principle must also be subject to a further qualification which ought to, but does not, ${ }^{10}$ go without saying. This is that the principle only applies in the absence of clear evidence of the actual mutual intention of the parties. That intention may be either that there is or is not a binding agreement. Dealing with the latter possibility first, it is clear, for example, that an apparently complete document which purports to be a contract will not be so where it is established by extrinsic evidence that it was not intended to be a binding agreement, either at all or until the fulfilment of a condition. Conversely, if there is proof of actual consensus ad idem and intention to be bound, there must surely be a contract regardless of what a reasonable person would infer from the parties' communications and the surrounding circumstances. Unless one is prepared to countenance the possibility of refusing to give effect to the parties' mutual subjective intentions, there is simply no reason to be concerned with, let alone give effect to, objective inferences. Indeed, it might be said that "if the mutual actual intention was that there should be a concluded contract, it would be fraudulent to deny that intent". ${ }^{11}$ Thus, the fact that there is no objective consensus ad idem because, for example, there is more than one reasonable interpretation of the obligations assumed, is irrelevant if the parties shared the same subjective understanding of the transaction. If in the famous case of Raffles $v$ Wichelhaus, ${ }^{12}$ which involved the sale of cotton "ex Peerless from Bombay" and there happened to be two ships named Peerless leaving Bombay at different times, the evidence established that both parties had the same Peerless in mind "it is clear that there would have been a valid contract, notwithstanding the objective ambiguity". ${ }^{13}$

Let us now apply these principles to the following simple example, bearing in mind that they are generally applicable regardless of the form of the alleged contract (which may be oral, written, or partly written and partly oral):

10 See "Actual Consensus" above $\mathrm{n} 1$.

11 Air Great Lakes Pty Ltd v K S Easter (Holdings) Pty Ltd [1985] 2 NSWLR 309, 319 per Hope JA. See generally the instructive judgments of Mahoney JA (esp 330-334) and McHugh JA (334339) in this case.

12 (1864) 2 H\&C 906; 159 ER 375.

13 J C Smith The Law of Contract (Sweet \& Maxwell, London, 1989) 14. See also Restatement (Second) of Contracts, § 20, Illustration 1; E A Farnsworth Farnsworth on Contracts (Little Brown, Boston, 1990) Vol II, 245-248; "Responsive Model" above n 4, 1123-1126; M A Eisenberg "Expression Rules in Contract Law and Problems of Offer and Acceptance" (1994) 82 Calif L Rev 1127, 1130-1135. 
$\mathrm{S}$ and B sign a document which is an apparently complete contract in which $\mathrm{S}$ promises to sell, and B promises to buy, a quantity of goods on certain stated terms. S later refuses to perform her promise, saying (truthfully) that she did not intend to make a binding contract.

Is there a contract? The answer is "probably, but not necessarily". There is a contract if, despite S's contrary subjective intention, B reasonably believed that $\mathrm{S}$ was making a binding contract. The need for security of transactions requires $S$ to be held to her apparent agreement. But there are several possible scenarios, which might be established by extrinsic evidence, in which there will not be a contract. First, notwithstanding that a reasonable bystander would infer from the parties' actions in signing the document that there existed a mutual intention to be bound, there will be no contract if it is proved that B shared S's intention that no contract should result; perhaps the parties were play-acting or intended a "gentlemen's agreement". Secondly, if B, though not sharing S's intention, knew or ought to have known of S's intention, there is no contract since B does not believe or does not reasonably believe that $S$ intends to be bound. Thirdly, $S$ may be able to establish that before the document was signed the parties agreed that it would not constitute a binding contract until the fulfilment of a certain condition; for example, approval of the agreement by another person. ${ }^{14}$ There is no breach of the parol evidence rule because that rule only applies once the existence of a contract is established.

It remains to note that, even if there is a contract, the document which the parties signed may not be the conclusive record of the terms of the contract. $\mathrm{S}$ may be able to establish by parol evidence that the document does not record the true consideration for the agreement, or that $\mathrm{B}$ made an oral promise which either gives rise to a collateral contract or is a term of a partly written and partly oral contract.

\section{PRINCIPLES OF CONTRACT INTERPRETATION}

Let us suppose now that it is admitted that the document was intended to be a binding contract and that it is an accurate record of the terms of the contract. However, an interpretation dispute later arises in which $S$ contends that certain words were used in a particular sense, and she points to pre-contract exchanges which show that B either agreed to that usage or led her reasonably to believe that he agreed to that usage. According to all the

14 Pym v Campbell (1856) 6 El \& Bl 370; 119 ER 903. See generally D W McLauchlan The Parol Evidence Rule (Professional Publications, Wellington, 1976) ch 12. 
leading expositions of the principles of contract interpretation by the Commonwealth Courts the evidence relied on by $S$ of the parties' negotiations or subjective intentions is inadmissible.

As I have attempted to demonstrate elsewhere, ${ }^{15}$ there is much confusion and inconsistency in the case law concerning the principles of contract interpretation. But one point on which there is almost unanimous agreement is that evidence of the parties' statements or conduct in the course of negotiations which reflects their subjective intentions is inadmissible. Even the more liberal versions of the relevant principles which favour "commonsense" or "commercial" interpretation and reject literalist tendencies embodied in the likes of the so-called plain meaning rule, accept that such evidence cannot be taken into account. It suffices to take Lord Hoffmann's influential recent summary, speaking for the majority of the House of Lords, in Investors Compensation Scheme Ltd v West Bromwich Building Society: ${ }^{16}$

(1) Interpretation is the ascertainment of the meaning which the document would convey to a reasonable person having all the background knowledge which would reasonably have been available to the parties in the situation in which they were at the time of the contract.

(2) The background was famously referred to by Lord Wilberforce as the "matrix of fact" but this phrase is, if anything, an understated description of what the background may include. Subject to the requirement that it should have been reasonably available to the parties and to the exception to be mentioned next, it includes absolutely anything which would have affected the way in which the language of the document would have been understood by a reasonable man.

(3) The law excludes from the admissible background the previous negotiations of the parties and their declarations of subjective intent. They are admissible only in an action for rectification. The law makes this distinction for reasons of practical policy and, in this respect only, legal interpretation differs from the way we would interpret utterances in ordinary life. The boundaries of this exception are in some respects unclear. But this is not the occasion on which to explore them.

(4) The meaning which a document (or any other utterance) would convey to a reasonable man is not the same thing as the meaning of its words. The meaning of words is a matter of dictionaries and grammars; the meaning of the document is what the parties using those words against the relevant background would reasonably have been understood to mean. The background may not

15 "Plain Meaning Rule" above n 1; "Subsequent Conduct" above n 1; and "Common Assumptions" above $\mathrm{n} 1$.

16 [1998] 1 WLR 896, 912-913 [Investors Compensation v West Bromwich]. 
merely enable the reasonable man to choose between the possible meanings of words which are ambiguous but even (as occasionally happens in ordinary life) to conclude that the parties must, for whatever reason, have used the wrong words or syntax: see Mannai Investments Co. Ltd v Eagle Star Life Assurance Co. Ltd [1997] AC 749.

(5) The "rule" that words should be given their "natural and ordinary meaning" reflects the common sense proposition that we do not easily accept that people have made linguistic mistakes, particularly in formal documents. On the other hand, if one would nevertheless conclude from the background that something must have gone wrong with the language, the law does not require judges to attribute to the parties an intention which they plainly could not have had ...

There are two key features of this account for present purposes. First, the task of a court when resolving an interpretation dispute is to ascertain the meaning which the document would convey to a reasonable person having knowledge of the background circumstances. "[T]he question is what reasonable persons, circumstanced as the actual parties were, would have had in mind". ${ }^{17}$ This impliedly rejects the view that it is a legitimate function of the Court in an interpretation dispute to determine, where possible, the sense in which the particular contracting parties used the language in question. ${ }^{18}$ Secondly, as a corollary of the above, evidence of the parties' negotiations or other exchanges which goes to show their actual intention and understanding is inadmissible. In so far as the negotiations "consist of statements and actions of the parties which are reflective of their actual intentions and expectations they are not receivable". ${ }^{19}$ The court can only look to "the objective framework of facts within which the contract came into existence, and to the parties' presumed intention

17 Mannai Investment Co Ltd v Eagle Star Life Assurance Co Ltd [1997] AC 749, 768 per Lord Steyn [Mannai v Eagle Star].

18 See, for example, Watcham v Attorney-General of the East Africa Protectorate [1919] AC 533, 538 (PC) and the instructive judgment of Thomas J in Attorney-General v Dreux Holdings Ltd (1996) 7 TCLR 617 (CA) which proceeds on the basis that the primary task of the court in an interpretation dispute is to seek and give effect to the meaning which the parties attributed to the words in question when the contract was signed.

19 Codelfa Construction Pty Ltd $v$ State Rail Authority of NSW (1982) 149 CLR 337, 352 per Mason J [Codelfa]. See also Commission for The New Towns v Cooper (Great Britain) Ltd [1995] Ch 259, 275-276 per Stuart-Smith LJ ("The contract is to be construed against the factual background or matrix in which it was made. The subjective intentions of the parties are irrelevant. The test is an objective one: what would a reasonable man, knowing the factual background, consider that the parties meant and intended from the language they used?"). 
in this setting". ${ }^{20}$ Interpretation of a contract requires "a purely objective assessment" of the contractual terms. ${ }^{21}$ The position was summarised by Lord Wilberforce in Reardon Smith Line Ltd $v$ Hansen-Tangen ${ }^{22}$ in the following well-known passage: ${ }^{23}$

When one speaks of the intention of the parties to the contract, one is speaking objectively - the parties cannot themselves give direct evidence of what their intention was - and what must be ascertained is what is to be taken as the intention which reasonable people would have had if placed in the situation of the parties.

\section{THE CONTRADICTION}

There could be no quarrel with the principles espoused by Lord Wilberforce and Lord Hoffmann to the extent that they simply opposed the parties giving "direct evidence of what their intention was" and excluded from the admissible background "their declarations of subjective intent". Not even the most liberal advocate of looser standards of contract interpretation would suggest that the parties should be able to go into the witness box and, with the benefit of hindsight, give their different and unsubstantiated versions of what they each meant. The position is entirely different, however, where there is reliable evidence of conduct or communications between the parties, whether in the course of their negotiations or afterwards, which lends support to a conclusion that they attached a particular meaning to the words in dispute at the time of the contract, or at least that one of them did and the other

20 Codelfa above $\mathrm{n} 19,352$.

21 McLaren $v$ Waikato Regional Council [1993] 1 NZLR 710, 731 per Fisher J (HC).

22 [1976] 1 WLR 989, 996 (HL).

23 The principle in this passage has been endorsed as representing New Zealand law in dozens of Court of Appeal and High Court cases. The following is a small selection of the Court of Appeal cases: Edwards v O'Connor [1991] 2 NZLR 542, 548-549 (plaintiffs successfully argued that "fishing licence" included quotas, but evidence of pre-contract discussions allegedly showing that this was what the parties meant - that they "had made their own dictionary" - was ruled inadmissible); Driffill v Frank Driffill Ltd (10 February 1988) unreported, CA 118/87 (McMullin J refers to "the wisdom" of the rule "because, in its absence, there would be no end to an exchange of views as to what each party had in mind"); Ravenwood v PG and SE Ballantyne Ltd (12 August 1988) unreported, CA 143/87; GSH Finance Pty Ltd $v$ Chase Securities Ltd (1988) 4 NZCLC 64,493, 64,503; American International Underwriters v Farmers Mutual Insurance Ltd (16 February 1995) unreported, CA 104/93; and Port of Wellington $v$ Longwith [1995] 1 ERNZ 87, 92. 
knew or had reason to know of this meaning. Nevertheless, it is clear that such evidence is also inadmissible under the principles described in the previous section.

In my view, the principle excluding evidence of the parties' negotiations and subjective intentions, though enshrined by authority, is simply unacceptable. There is no sensible reason why the interpretation process required to determine whether a contract was formed should differ so fundamentally from the process required to determine the meaning of that contract. The strict objective approach which seeks to discover the "presumed intent" is fair enough when, as frequently happens, the parties did not contemplate the situation which has arisen, but it is entirely another matter to elevate it to a universal rule and to reject out of hand what may be relevant and reliable evidence from the negotiations of the meaning they actually attributed to the words of the contract. Such evidence should be equally as relevant as evidence of their actual intention to be bound to a contract. This is particularly so when it is considered that disputes over the meaning of contractual language will very often call into question whether, due to misunderstanding between the parties, a binding contract was formed in the first place. ${ }^{24}$ Let us take two examples built around the facts of the celebrated American case of Frigaliment Importing Co Ltd $v$ BNS International Sales Corp: ${ }^{25}$

$S$ and B enter into a written agreement for the sale of a large quantity of "chicken" meeting certain detailed specifications as to weight, packaging and so on. The first shipment meets these specifications but it is rejected by B on the ground that it is stewing chicken. When $S$ sues for damages, B counterclaims arguing that the word "chicken" meant young birds for frying or broiling as opposed to "fowl" which were more mature birds suitable only for stewing. B refers to evidence in the pre-contract exchanges suggesting that the parties contemplated delivery of young chicken (or that, at least, $S$ ought to have known that B intended young chicken). Such evidence is inadmissible and $S$ will be entitled to succeed if a reasonable third party with knowledge of the background circumstances other than the negotiations would conclude that a shipment of fowl was performance within the meaning of the word "chicken".

The facts are the same except that B argues in the alternative that, since the parties were not ad idem, no binding contract was formed. This defence will succeed if the evidence establishes that $S$ knew or ought to have known that B only intended to buy young chicken. For this purpose evidence of the parties' negotiations is clearly admissible.

24 See, for example, the first two defences put forward in Engineering Plastics Ltd $v$ J Mercer $\mathcal{E}$ Sons Ltd [1985] 2 NZLR 72, 77-79 (HC).

25 (1960) 190 F Supp 116 (SD NY). 
Two observations are immediately prompted by these examples. First, in the former it is artificial in the extreme to talk about a reasonable third party with knowledge of the background if the most pertinent circumstances, the pre-contract exchanges, are excluded. The position would presumably be different if, for example, $\mathrm{S}$ were aware from previous dealings between the parties that when B used the word "chicken" he meant young birds. These previous dealings would be admissible as relevant background in determining the meaning which the words would convey to a reasonable person in S's position. It is difficult to fathom why negotiations should be treated differently in this regard.

Secondly, and more importantly, in the latter example it will usually be a short step from a finding that $\mathrm{S}$ ought to have known B's intention to a conclusion that $\mathrm{S}$ led B reasonably to believe that the subject of the sale was young chicken. If so, that surely was the contract. We are back then to square one. The answer to the first example must be wrong. B's counterclaim for damages should succeed.

\section{MORE OBJECTIONS/CONTRADICTIONS}

There are numerous other reasons why it is necessary to reject the principle that evidence of the parties' negotiations and subjective intentions is not receivable in an interpretation dispute.

\section{A Private Conventions}

There can be no objection in principle to the parties to a written contract being able to choose their own private, and perhaps secret, code or convention as to the meaning of the terms of the contract. As Corbin points out: ${ }^{26}$

26 AL Corbin Corbin on Contracts (1st rev ed, West Publishing Co , St Paul, 1960) vol 3, para 544, 157. See also para 540, 93-94. Compare Holmes, "The Theory of Legal Interpretation" (1898-99) 12 Harv L Rev 417, 420: "I do not suppose that you could prove, for purposes of construction as distinguished from avoidance, an oral declaration or even an agreement that words in a dispositive instrument making sense as they stand should have a different meaning from the common one; for instance, that the parties to a contract orally agreed that when they wrote five hundred feet it should mean one hundred inches, or that Bunker Hill Monument should signify Old South Church." Wigmore (Wigmore on Evidence (Chadbourn rev, Little Brown, Boston, 1981) vol 9, para 2462) responds by observing: "Now the interesting feature of this illustration is that in important instances the very opposite fact is daily and hourly illustrated - in the private cipher codes of commercial houses. By these agreements words are employed in a sense totally alien and sometimes exactly opposite to the ordinary meaning... [S]ome brokers who are particularly apprehensive of the 
Suppose that when A is about to write down the terms of an agreement, he says to B: Please note that when I write herein the words "my house" I shall mean the house on Salem Street owned by my wife; that the words "500 feet" shall mean 100 inches; that by the name "John Doe" I shall mean Friar Tuck; that "Bunker Hill Monument" shall mean Old South Church; and that the words "my children" shall mean my two illegitimate children and not my three legitimate ones. The following document is thereupon written out and signed by A and B: "It is mutually agreed that I (A) will convey my house to John Doe and B promises in return to convey to my children the building situated just 500 feet south of Bunker Hill Monument." A valid contract has been made. It means what A told B that it should mean. And the process of determining this meaning is a process of interpretation by means of A's special code, and not [rectification] for mistake in expression.

This view is now reflected in $\S 212$ of the Restatement (Second) of Contracts where the following illustration is given:

4. $\quad A$ and $B$ are engaged in buying and selling shares of stock from each other, and agree orally to conceal the nature of their dealings by using the word "sell" to mean "buy" and using the word "buy" to mean "sell". A sends a written offer to B to "sell" certain shares, and B accepts. The parties are bound in accordance with the oral agreement.

On the Corbin and Restatement approach, Gallen J is simply wrong when he says in Benjamin Developments Ltd $v$ Robt Jones (Pacific) $L t d{ }^{27}$ the leading New Zealand case on the plain meaning rule:

If a contract refers to apples, then it will not be open to parties to aver that the real intention was to refer to pears.

interception of their messages are accustomed to agree that 'buy' shall mean 'do not buy'. . .". For Corbin's response see para 544, n 96.

27 [1994] 3 NZLR 189, 207 (CA). A similar view to that of Gallen J is expressed by Clarke JA in Trawl Industries of Australia Pty Ltd v Effem Foods Pty Ltd (1992) 27 NSWLR 326, 362: "I am prepared to accept that the parties may include in their written agreement a definition of a phrase used in that agreement which would indicate they had used that phrase to convey a meaning which it otherwise was not capable of bearing. It is otherwise if a party seeks to rely on an antecedent oral agreement to support a contention that the word or phrase in the written agreement bore an agreed meaning which, as a matter of English, it was not capable of bearing. In that instance the oral agreement would contradict the written contract and the parol evidence rule would prevent its reception into evidence." 
There may be clear unimpeachable evidence that the parties, perhaps because they wished to keep the nature of their dealings secret from others, had a long-standing private code whereby "apples" did mean "pears". Of course, the existence of such a code is inherently unlikely. But, as I have argued elsewhere, ${ }^{28}$ that is a matter going to the weight of evidence needed to rebut the presumption that the parties used language bearing its ordinary meaning.

\section{B Common Assumptions}

There is authority for an important exception to the rule that evidence of the parties' negotiations and subjective intentions is inadmissible, an exception which has the potential to "swallow up the rule". ${ }^{29}$ In the recent case of Air New Zealand Ltd $v$ The Nippon Credit Bank $L t d,{ }^{30}$ the New Zealand Court of Appeal endorsed the following principle concerning the interpretation of written contracts laid down by Kerr J in The Karen Oltmann: ${ }^{31}$

If a contract contains words which, in their context, are fairly capable of bearing more than one meaning, and if it is alleged that the parties have in effect negotiated on an agreed basis that the words bore only one of the two possible meanings, then it is permissible for the Court to examine the extrinsic evidence relied upon to see whether the parties have in fact used the words in question in one sense only, so that they have in effect given their own dictionary meaning to the words as the result of their common intention.

I have fully discussed the implications of this principle elsewhere, ${ }^{32}$ but a number of points perhaps bear repetition. First, as the Court of Appeal acknowledged, there is a "fine line ... between evidence showing that the parties proceeded on a common assumption as to the effect of their contract or the meaning of a word in it, which may be admitted, and evidence of their pre-contract negotiations (unless they otherwise evidence the common assumption just referred to) and subjective intentions, which may not". ${ }^{33}$ Secondly, why should the exception be confined to situations where the words of the contract are ambiguous or "fairly (1988) 41 CLP 23, 29.

30 [1997] 1 NZLR 218 (CA, Gault, McKay and Thomas JJ).

31 Partenreederei MS Karen Oltmann v Scarsdale Shipping Co Ltd [1976] 2 Lloyd's Rep 708, 712.

32 "Common Assumptions" above $\mathrm{n} 1$.

33 Above n 30, 224. 
capable of bearing more than one meaning"? Should the parties' common intention be defeated because the words in question appear to the court to have a plain meaning? Where there is convincing evidence that at the time of the contract the parties attached the same meaning to the words in dispute, the task of the court is to give effect to that meaning, regardless of whether those words on their face are ambiguous or have a plain meaning. On this approach, just as "parties may for the purposes of a particular transaction agree . . that black shall mean white and vice versa" so as to give rise to an estoppel by convention, ${ }^{34}$ such agreement should also establish their meaning for the purposes of an interpretation dispute. Thirdly, why should the exception be limited to evidence of actual common intention? Surely the position should be no different where, for example, the evidence may establish that one party intended the particular meaning and that party reasonably believed that the other party accepted this meaning. It would be a strange twist in the law if such an objectively determined agreement as to meaning did not suffice.

\section{Common Rejection of Meaning}

Even the staunchest advocates of the strict objective approach to contract interpretation would probably acknowledge the need for exceptions. Thus, in the leading decision of the High Court of Australia in Codelfa Construction Pty Ltd $v$ State Rail Authority of NSW, ${ }^{35}$ Mason J, after stressing that evidence of statements and actions in the course of the parties' negotiations "which are reflective of their actual intentions and expectations" is not admissible, was prepared to concede that "[t]here may perhaps be one situation in which evidence of the actual intention of the parties should be allowed to prevail over their presumed intention". ${ }^{36}$ His Honour continued: ${ }^{37}$

If it transpires that the parties have refused to include in the contract a provision which would give effect to the presumed intention of persons in their position it may be proper to receive evidence of that refusal. After all, the court is interpreting the contract which the parties have made and in that exercise the court takes into account what reasonable men in that situation would have intended to convey by the words chosen. But is it right to carry that exercise to the point of placing on the

34 National Westminster Finance NZ Ltd $v$ The National Bank of NZ Ltd [1996] 1 NZLR 548, 550 (CA).

35 Codelfa above $\mathrm{n} 19$.

36 Codelfa above n 19, 352.

37 Codelfa above n 19, 352-353. 
words of the contract a meaning which the parties have united in rejecting? It is possible that evidence of mutual intention, if amounting to concurrence, is receivable so as to negative an inference sought to be drawn from surrounding circumstances.

It is difficult to see any sensible basis for limiting the admissibility of evidence of the parties' actual intention to the situation where they have refused to include a particular provision in the contract. Their actual intention, if clearly proven, surely ought to prevail regardless of the form or manner in which that intention happens to be manifested. Why allow evidence of the fact that the parties have "united in rejecting" a particular meaning but disallow evidence of the fact that they have united in accepting a particular meaning? ${ }^{38}$

\section{Absence of Practical or Policy Grounds for Exclusion}

It will be recalled that in Investors Compensation Scheme Ltd $v$ West Bromwich Building Society ${ }^{39}$ Lord Hoffmann referred to, but did not elaborate on, "reasons of practical policy" for excluding "from the admissible background the previous negotiations of the parties and their

The difficulties and inevitable distortions caused by the strict objective approach are further illustrated by the judgment of Santow J in Spunwill Pty Ltd v BAB Pty Ltd (1994) 36 NSWLR 290 which concerned the question of the admissibility of evidence of post-contractual conduct as an aid to interpretation of an ambiguous contract. His Honour accepted that it was a settled principle of contract interpretation that the object is to give effect to the apparent or presumed intention of the parties and hence "direct evidence of the parties' actual subjective intentions and expectations is inadmissible" (299). However, in order to justify reception of evidence of the parties' actual intention, and in particular evidence of their subsequent conduct, his Honour went on to argue that "matters of mutual subjective intention are themselves part of the objective framework of facts within which the contract came into existence, and are thus receivable as part of the surrounding factual circumstances" (309). In other words, "evidence of a mutual subjective intention is admissible ... as an objective fact that illuminates the meaning a reasonable person in the position of the parties would attach to a provision" (310). Consistently with this approach, but contrary to my view, the judge accepted that the existence of a mutual subjective intention - an objectively determined "shared subjectiveness"! (309) - was simply one "factor to be taken into account in determining presumed intention, without necessarily being determinative" (310). This is because "[e]xtrinsic evidence of facts, statements and conduct known to both parties" is only admissible to "illuminate the meaning that reasonable persons in the position of the parties objectively intended ambiguous language of the document to bear. Extrinsic evidence which merely illuminates the actual subjective intentions, aspirations or expectations of the parties does not assist in discovering the presumed intention and is inadmissible." (309). See further "Subsequent Conduct" above n 1, 252-254.

Above n 16, 913. 
declarations of subjective intent". His Lordship perhaps had in mind the observation of Lord Wilberforce in Prenn $v$ Simmonds that the reason: ${ }^{40}$

is not a technical one or even mainly one of convenience, (though the attempt to admit it did greatly prolong the case and add to its expense). It is simply that such evidence is unhelpful. By the nature of things, where negotiations are difficult, the parties' positions, with each passing letter, are changing and until the final agreement, though converging, still divergent. It is only the final document which records a consensus ... [I]t may be a matter of degree, or of judgment, how far one interpretation, or another, gives effect to a common intention: the parties, indeed, may be pursuing that intention with differing emphasis, and hoping to achieve it to an extent which may differ, and in different ways. The words used may, and often do, represent a formula which means different things to each side, yet may be accepted because this is the only way to get "agreement" and in the hope that disputes will not arise.

This reasoning is entirely unconvincing. As the examples discussed in this paper demonstrate, evidence of the parties' negotiations will sometimes be very helpful and, in my view, the points made by Lord Wilberforce are only valid as cautionary factors to be taken into account in determining the weight to be given to evidence of prior negotiations, not its admissibility.

Lord Hoffmann may also have had in mind the kind of practical and policy reasons which have been used over the years to justify the plain meaning rule of contract interpretation, albeit that he viewed the latter more as a commonsense starting-point rather than a "rule". These reasons relate to the need for certainty, particularly in commercial transactions, and the desirability of not prolonging civil trials through the reception of vast quantities of extrinsic evidence, much of which may be unhelpful, irrelevant or unreliable.

Such considerations tend to have found a receptive ear in the New Zealand courts of late, particularly in the Court of Appeal. This is reflected in Cooke P's frequently cited admonition in Masport Ltd $v$ Morrison Industries Ltd: ${ }^{41}$

40 [1971] 1 WLR 1381, 1384-1385 (HL).

41 (31 August 1993) unreported, Court of Appeal, CA 362/92. See also Benjamin Developments Ltd $v$ Robt Jones (Pacific) Ltd above n 27, 196 and Board of Trustees of the National Provident Fund $v$ Shortland Securities Ltd [1996] 1 NZLR 45, 50 (CA) 
Businessmen and lawyers are often loud in their stress on the need for certainty in commercial law. When it seems expedient, however, many are ready to destroy certainty by contending that an apparently complete written bargain was not what it seemed.

However, this observation was made not in the context of an interpretation dispute but in response to an attempt to establish the existence of contractual terms not recorded in the parties' written contract. Given the numerous well established exceptions to the parol evidence rule under which such a result can be achieved nowadays, the judge's sentiments are hardly persuasive.

\section{The argument from certainty}

The argument from certainty might have some merit were it not for the fact that the outcome of interpretation disputes is so notoriously difficult to predict anyway. ${ }^{42}$ Time and again in recent years judges have disagreed not only on the correct approach but also on such elementary questions as whether particular words have a plain meaning ${ }^{43}$ and what is the "commonsense" or "commercially realistic" interpretation. ${ }^{44}$ Remarkably, in the period June 1996 - December 1997, six decisions of the Court of Appeal, none of which raised issues of general principle, were the subject of appeals to the Privy Council and of these four were

42 See the recent majority decisions of the House of Lords, reversing the Court of Appeal, in Deutsche Genossenschaftsbank v Burnhope [1996] 1 Lloyd's Rep 113, Mannai v Eagle Star above $\mathrm{n}$ 17, and Investors Compensation $v$ West Bromwich above $\mathrm{n} 16$. These cases are usefully discussed by G McMeel, "The Rise of Commercial Construction in Contract Law" [1998] LMCLQ 382.

43 See, for example, Melanesian Mission Trust Board v Australian Mutual Provident Society [1997]1 NZLR 391 (Privy Council upholding dissenting judgment of Henry J in the Court of Appeal that the words in dispute were "clear and unambiguous") and Sunflower Services Ltd $v$ Unisys New Zealand Ltd [1997] 1 NZLR 385.

44 See Lim $v$ McLean [1997] 1 NZLR 641 (majority of Privy Council upheld an interpretation which the two dissenting judges (649) and three Court of Appeal judges thought made "no sense commercially"), Deutsche Genossenschaftsbank $v$ Burnhope above n 42 (majority of House of Lords accepting an interpretation which was rejected by the Court of Appeal and castigated by Lord Steyn as contrary to "business common sense" (124)), and Centrax Ltd v Citibank NA (4 March 1999) English Court of Appeal (Waller LJ, dissenting, could see "nothing irrational" in an interpretation which Roch LJ, with whom Ward LJ concurred, described as a "commercial absurdity" and as "flout[ing] common sense"). 
successful ${ }^{45}$ and one was dismissed by a bare 3:2 majority. ${ }^{46}$ Furthermore, it is not difficult to identify other cases in which appeals from highly debatable decisions of the Court of Appeal were not pursued. ${ }^{47}$

\section{Considerations of convenience and efficiency}

The policy reasons for not allowing parol evidence to be admitted in aid of interpretation when the words appear to be plain and clear have been expressed by Kirby P (as he then was) as follows: ${ }^{48}$

The social purpose ... is to discourage litigation, with the time consuming, costly and dilatory exploration of detailed facts and the resolution of conflicts of recollection and testimony. It is to discourage curial exploration of the unfathomable depths of subjective intentions. It is to add to certainty by adherence to the effect of the clearly expressed written word.

However, in so far as this statement refers to considerations of efficiency and convenience, it ignores the reality that many interpretation disputes will be accompanied by alternative claims for rectification of the written contract (and possibly also misrepresentation or estoppel) under which evidence of all the negotiations and surrounding circumstances must be received. ${ }^{49}$ Accordingly, excluding such evidence for the purpose of interpretation disputes will not have the effect of reducing the length and cost of civil trials. Furthermore, even in the absence of alternative claims, a court will invariably be obliged to admit and listen to the extrinsic evidence for the purpose of determining the application of an acknowledged

45 Melanesian Mission Trust Board v Australian Mutual Provident Society above n 43, Sunflower Services Ltd $v$ Unisys New Zealand Ltd above n 43, Lim v McLean above n 44, and New Zealand Forest Products Ltd v New Zealand Insurance Co Ltd [1997] 1 WLR 1237.

46 Nippon Credit Bank Ltd v Air New Zealand Ltd (1997) 8 TCLR 106, [1998] 2 NZLR 1 (note). The other case was Board of Trustees of the National Provident Fund $v$ Shortland Securities Ltd [1997] 1 NZLR 1.

47 See, for example, BP Oil NZ Ltd v Rhumvale Resources Ltd (1998) 8 TCLR 116.

48 BEB Constructions (Aust) Pty Ltd v Brian A Cheeseman $\mathcal{E}$ Associates Pty Ltd (1994) 35 NSWLR $227,234$.

49 See, for example, Attorney-General v Dreux Holdings Ltd (1996) 7 TCLR 617 and Melanesian Mission Trust Board $v$ Australian Mutual Provident Society above $\mathrm{n}$ 43. In Prenn $v$ Simmonds above $n$ 40, 1383 Lord Wilberforce observed that the alternative claim for rectification "let in a mass of evidence, oral and documentary as to the parties' intentions, which would not be admissible on construction". 
exception to the plain meaning rule. For example, it may be contended that the result of the application of the words in their "plain and ordinary" sense is so absurd that another meaning must have been intended.

The reference to the need "to discourage curial exploration of the unfathomable depths of subjective intentions" echoes Tindal CJ's well known justification for the plain meaning rule in Shore $v$ Wilson: $:^{50}$

If it were otherwise, no lawyer would be safe in advising upon the construction of a written instrument, nor any party in taking under it; for the ablest advice might be controlled and the clearest title undermined, if, at some future period, parol evidence of the particular meaning which the party affixed to his words, or of his secret intention in making the instrument, or of the objects he meant to take benefit under it, might be set up to contradict or vary the plain language of the instrument itself.

The fallacy of the assumption in this passage that there is a uniformity and certainty in the meaning of language has often been exposed. ${ }^{51}$ However, there is also the further point that a relaxation of the plain meaning rule would not let in evidence of a party's "secret intention in making the instrument". ${ }^{52}$ Neither the thoughts nor the acts of one party preceding the execution of a written contract and not communicated to the other party are relevant to the interpretation of a contract. It must be stressed that there is nothing in this article to suggest that a court should be able to interpret the words of an agreement in accordance with the unexpressed intention of one of the parties. (It would be entirely another matter, of course, if that unexpressed intention were shared by the other party and hence there happened to be an actual consensus ad idem on the point. ${ }^{53}$ )

$50 \quad$ (1842) 9 Cl \& Fin 355, 566; 8 ER 450, 532-533.

51 See "Plain Meaning Rule" above n 1.

52 Compare McLaren $v$ Waikato Regional Council above n 21, 731 where Fisher J refers variously to the irrelevancy of "what the parties privately thought", "the subjective intentions of the parties", and "the unexpressed thoughts of the parties".

53 But contrast the view of the English Court of Appeal in New Hampshire Insurance Co $v$ MGN Ltd (15 June 1995) unreported, The Times, 25 July 1995. Staughton LJ (with whom Millett and Ward L JJ agreed) adopted the "first principle" that "nothing is relevant to the interpretation of a written contract unless it was known to, or reasonably capable of being known to, both parties at the time when the contract was made" and concluded from this that evidence that both parties had held the same undisclosed intention as to the meaning or effect of the contract was inadmissible. 


\section{E Admissibility of Evidence of Subsequent Conduct}

If, as appears from Attorney-General $v$ Dreux Holdings $L t d^{, 54}$ the Court of Appeal is now leaning in the direction of allowing evidence of the parties' post-contract conduct as an aid to determining the meaning which they attributed to the contract when it was signed, evidence of their negotiations and other pre-contract indicators of their actual intention ought also to be admissible. For, as Lord Wilberforce pointed out in L Schuler AG v Wickman Machine Tool Sales $L t d{ }^{55}$ "[i]t is one and the same principle which excludes evidence of statements, or actions, during negotiations, at the time of the contract, or subsequent to the contract". 56 Further, it would not be sensible for the court to allow evidence of subsequent conduct and at the same time continue to assert, on the basis of the leading English authorities concerning the admissibility of extrinsic evidence, ${ }^{57}$ that "the interpretation of contracts is not a matter for evidence of the intentions or understandings of the parties". 58

\section{F Implications of UN Sales Convention}

Further compelling cause to re-evaluate the principles of contract interpretation arises as a result of New Zealand's implementation of the United Nations Convention on Contracts for the International Sale of Goods which came into force on 1 October $1995 .{ }^{59}$ Included amongst the new rules governing international sales contracts are liberal provisions for the interpretation of contracts which reflect the approach advocated in this article. Thus, under Article $8(1)$ statements made by a party "are to be interpreted according to his intent where the other party knew or could not have been unaware what that intent was". Article 8(2) provides that, if the latter provision is inapplicable, a party's statements "are to be interpreted according to the understanding that a reasonable person of the same kind as the other party would have had in the same circumstances". Further, under Article 8(3), "[i]n determining

54 Above $\mathrm{n} 49$.

$55 \quad$ [1974] AC 235, $261(\mathrm{HL})$.

56 See also McLaren $v$ Waikato Regional Council above n 21, 725 where Fisher J observes that it is an established principle of construction that "[t]he subjectively considered intentions and meanings of the parties before, during and after the contract are irrelevant".

57 Prenn $v$ Simmonds above $\mathrm{n} 40$ and Reardon Smith Line Ltd $v$ Hansen-Tangen above n 22.

58 Port of Wellington Ltd v Longwith [1995] 1 ERNZ 87, 92 (CA).

59 Sale of Goods (United Nations Convention) Act 1994. The Sale of Goods (United Nations Convention) Act Commencement Order 1995 brought the Act into force on 1 October 1995. 
the intent of a party or the understanding a reasonable person would have had, due consideration is to be given to all relevant circumstances of the case including the negotiations, any practices which the parties have established between themselves, usages and any subsequent conduct of the parties".

I have referred on previous occasions to the obvious need for harmonisation of the interpretation rules for domestic contracts with the Convention's rules for international sales. ${ }^{60}$ Here it suffices to observe that it would be quite odd if it were the law of New Zealand that evidence of the parties' negotiations and subjective intentions were admissible to aid the interpretation of international sales contracts but not other commercial contracts, or indeed contracts generally.

\section{G Unidroit Principles of International Commercial Contracts}

The Unidroit Principles of International Commercial Contracts, published in 1994, add further weight to the arguments based on the implementation of the international sales convention, particularly bearing in mind the Court of Appeal's recent observation that "[t]here is something to be said for the idea that New Zealand domestic contract law should be generally consistent with the best international practice". ${ }^{61}$ The Unidroit Principles, which are "in the nature of a restatement of the commercial contract law of the world"62 and which are likely to become highly influential in the resolution of international commercial disputes, ${ }^{63}$ refine and expand the principles contained in the convention. The interpretation provisions begin with Article 4.1 which provides:

(1) A contract shall be interpreted according to the common intention of the parties.

60 "Plain Meaning Rule" above n 1, 97 and "Subsequent Conduct" above n 1, 254.

61 Attorney-General v Dreux Holdings Ltd above n 49, 627. See also the less equivocal observation of Thomas J in this case that "it is clearly desirable that the approach of the Courts in this country to the interpretation of contracts coincides, as far as is possible, with international practice" (642).

62 Joseph M Perillo "Unidroit Principles of International Commercial Contracts: The Black Letter Text and a Review" (1994) 63 Fordham L Rev 281, 283.

63 See Whitmore Gray "Globalisation of Contract Law: Rules for Commercial Contracts in the 21st Century" [1996] NZLJ 52; David AR Williams "The Further Development of International Commercial Arbitration through the Unidroit Principles of International Commercial Contracts" (1996) 2 NZ Business LQ 7; and MP Furmston "Unidroit Principles for International Commercial Contracts" (1996) 10 JCL 11. 
(2) If such an intention cannot be established, the contract shall be interpreted according to the meaning that reasonable persons of the same kind as the parties would give to it in the same circumstances.

Articles 4.2 and 4.3 contain a redraft of the interpretation principles in the sales convention and, needless to say, allow reference to "preliminary negotiations between the parties". 64

\section{CONCLUSION}

This article has attacked the notion that, in the context of an interpretation dispute, the court can only look to "the objective framework of facts within which the contract came into existence, and to the parties' presumed intention in this setting". 65 For the many reasons discussed, not the least of which is the inconsistency with principles of contract formation, it is impossible to accept this extreme version of the objective theory under which the actual intentions and expectations of the parties are to be rejected in favour of the intention which a reasonable third party would have inferred. If, as presumably few would deny, the primary purpose of the law of contract is to give effect to the reasonable expectations of the parties to an agreement, it is nonsensical to enforce an agreement in accordance with a meaning which reliable evidence may show is contrary to the actual intentions of the parties.

64 Article 4.3(a).

65 Codelfa above $\mathrm{n} 19,352$. 
